УДК 351.72:336.14

DOI: $10.34132 /$ pard2020.10.02

\title{
ОБГРУНТУВАННЯ НАПРЯМКІВ ДЕРЖАВНОГО УПРАВЛІННЯ У СФЕРІ ГЕНДЕРНО-ОРІСНТОВАНОГО БЮДЖЕТУВАННЯ
}

Білик О. I. канд. екон. наук, доцент, Національний університет «Львівська політехніка», м. Львів, Україна.

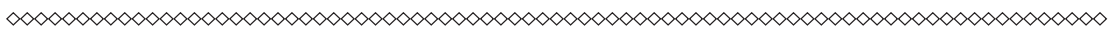

У статті висвітлено особливості гендерного бюджетування $i$ необхідності його застосування в системі державного управління. Висвітлені тези щуодо гендерно-орієнтованого бюджетування $в$ державному управлінні базуються на досвіді розвинених країн світу, з врахуванням проблем, пов>язаних з гендерним бюджетуванням, 3 метою дослідження та обтрунтування напрямів дій на момент початку прочесу інтеграчії гендерного державного управління. Протягом останніх 25 років міжнародне співтовариство визнало, щзо тендерна рівність має важливе значення для стійкого економічного зростання та повного соціального розвитку, $i$ закликало краӥни використовувати свої бюджети для сприяння розподілу ресурсів та отримання доходів за рівною гендерною ознакою. Більше 60 крайн відповіли на цееи заклик, впровадивши бюджети, щзо враховують гендерні аспекти, на начіональному та субначіональному рівнях. Доведено, що саме застосування гендерно-чутливого бюджетування в системі державного управління дозволить мінімізувати соџіальні ризики, які можуть деструктивно впливати на державні фінанси. B статті розкрито можливі стратегї гендерно-орієнтованого бюджетування, а також запропоновано якісний метод визначення пріоритетності впровадження тих чи інших гендерних програм, побудованого на а/в-тестуванні.

Ключові слова: гендерно-орієнтоване бюджетування, державне управління, стратегії гендерно-орієнтованого бюджетування, а/втестування, сочіальні ризики, гендерно-чутливі сфери. 
Постановка проблеми у загальному вигляді. Гендерна рівність та розширення прав і можливостей жінок були в центрі суспільних дебатів протягом декількох десятиліть, і політики та державні менеджери приділяли все більшу увагу тому, як державна політика може по-різному впливати на жінок та чоловіків. Це спричинило необхідність розробки документів з питань гендерного бюджетування, де гендерні перспективи вводяться в бюджет як інструмент державного управління, 3 метою підвищення контрольованості і покращення регулювання доходів та видатків країн світу. Концепція була введена в Австралії вже у 1980-х роках, але саме Всесвітня конференція з питань жінок у Пекіні в 1995 р. створила основу для гендерного бюджетування. Однак рамки, вказівки та обов>язкові вимоги до таких професійних органів, як МВФ, ОЕСР або ООН, сприяли поширенню вимог до створення гендерно-чутливих програм у країнах, що розвиваються, зокрема поряд 3 реформами бюджетування та бухгалтерського обліку. Сьогодні десятки країн у всьому світі реалізували ініціативи 3 питань гендерного бюджетування, і переважна більшість країн ОЕСР (90 \%) звітують про використання інструментів для сприяння гендерній рівності. Однак дослідження про напрямки впровадження гендрено-чутливого бюджетування в Україні, а також особливості державного управління у цій сфері, окрім напрямків, які розглядають дизайн ініціатив 3 питань гендерного бюджетування, є обмеженими. Наразі лише кілька досліджень присвячені впровадженню гендерних перспектив у бюджетні процеси, розглядаючи лише гендер, як досягнення рівності і $є$ проміжним кроком для встановлення напрямків удосконалення державного управління у цій сфері.

Аналіз останніх досліджень та публікацій. Початок наукових досліджень щодо гендерної нерівності можна віднести до кінця 1960-х , що висвітлювала у своїх працях А. Майхофер [1, с. 65], М. Гайстер [2, с.5] обгрувантувала необхідність сприяння зайнятості жінок, про те, що жінка $\epsilon$ могутнім економічним фактором. Я. Гензель досліджує особливості ролі жінки в умовах пандемії [3]. Удосконалений «підхід до спроможності» до гендерного бюджетування, запропонований А. Сен [4], яка пропонувала 
«орієнтовану на людей альтернативу утилітарним підходам до добробуту, керованих макроекономікою», розробила С. Хагман [5]. Серед вітчизняних досліджень, слід відзначити дослідження T. Огородової, яка у своїй праці обгрунтоввала необхідність і важливість впровадження гендерно-орієнтованого бюджетування та його переваги [6]. Науковим осмислення переваг гендерного бюджетування стала праця І. Грицай [7], Л. Наливайко [8]. Проблеми гендерного аналізування і шляхи їх вирішення розкрила Т. Фесенко [9]. Проте, на сьогодні в умовах несприйняття в Україні проблем гендеру, важливим є питання обгрунтування напрямків державного управління цієї сфери.

Формулювання цілей статті (постановка завдання). Метою статті є дослідження та побудова напрямків державного управління у сфері гендерно-орієнтованого бюджетування.

Викладення основного матеріалу дослідження. Результати опитування бюджетних практик та процедур ОЕСР на 2018 рік показують, що гендерне бюджетування стає все більш популярним серед країн ОЕСР. Зараз майже половина країн ОЕСР (17) запровадила гендерне бюджетування порівняно 312 у 2016 році. 317 країн OECP [10], які вже запровадили гендерне бюджетування, більше половини мають законодавчі положення, що лежать в основі цієї практики (Австрія, Бельгія, Канада, Ісландія, Італія, Корея, Мексика, Норвегія, Португалія та Іспанія). Правовий фундамент може сприяти захисту гендерного бюджету від коливань, що виникають внаслідок короткострокового економічного чи політичного контексту.

Практика гендерного бюджетування здебільшого була впроваджена протягом останнього десятиліття. Рис.1 ілюструє відносну важливість різних факторів у впровадженні гендерного бюджетування. Фактор, який найчастіше вказаний як основну причину впровадження гендерного бюджетування, сприймається нерівністю (вісім країн ОЕСР 3 12, які запровадили гендерне бюджетування). Половина цих країн також заявили, що основним фактором було те, що гендерне бюджетування є одним із аспектів гендерної інтеграції (шість із 12 країн ОЕСР). Необхідно визначити ряд причин впровадження гендрено- орієнтованого бюджетування 


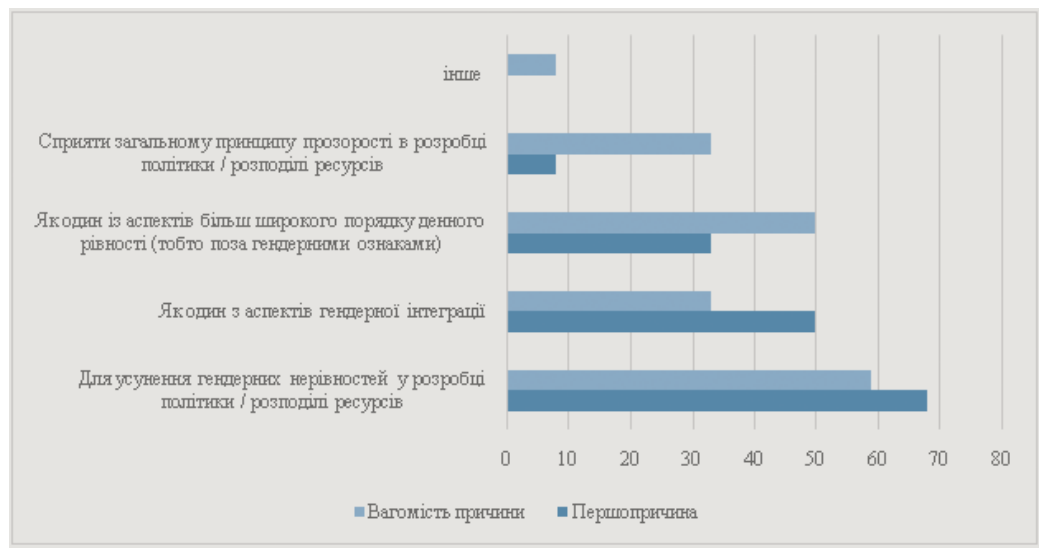

Puc.1. Причини введення гендерно-орієнтованого бюджетування у країнах ОЕСР[11]

Таким чином, алгоритм впровадження ГОБ на державному рівні має враховувати різні аспекти (рис. 2). Бюджетний процес та діяльність бюджетної групи, яку він виробляє, можуть бути розглянуто 3 точки зору чотирьох основних етапів: складання, прийняття законодавства, здійснення та аудиту.

Однак корисно мати на увазі наступні умови:

- сам процес бюджету не розділений чітко на етапи. На практиці етапи перекриваються. Так само робота бюджетних груп зазвичай триває не один етап.

- бюджетний процес у кожному контексті регіону країни пропонує унікальний набір можливостей та обмежень. Групи обирають, як розподілити свої ресурс залежно від відносних можливостей у кожній точці процесу.

Цілі ГОБ можуть певною мірою розглядатися як ієрархічні. На початковому етапі впровадження у багатьох країнах, ГОБ зазвичай зосереджуються на стратегіях, спрямованих на підвищення обізнаності про гендерну політику та бюджети (наприклад, збір даних, розділених за статтю, підготовка державних службовців, розробка гендерно-чутливого аналізу). Однак хороша інформація та 
аналіз гендерних питань та наслідків політики та бюджету самі по собі не є достатніми для зміни бюджетів, якщо державні чиновники не можуть бути покликані виконувати свої дії у сфері гендерної рівності. Відповідно, мета сприяння відповідальності уряду за зобов>язаннями щодо гендерної рівності може розглядатися як друга передумова зміни бюджетів та політики на стійкій основі.

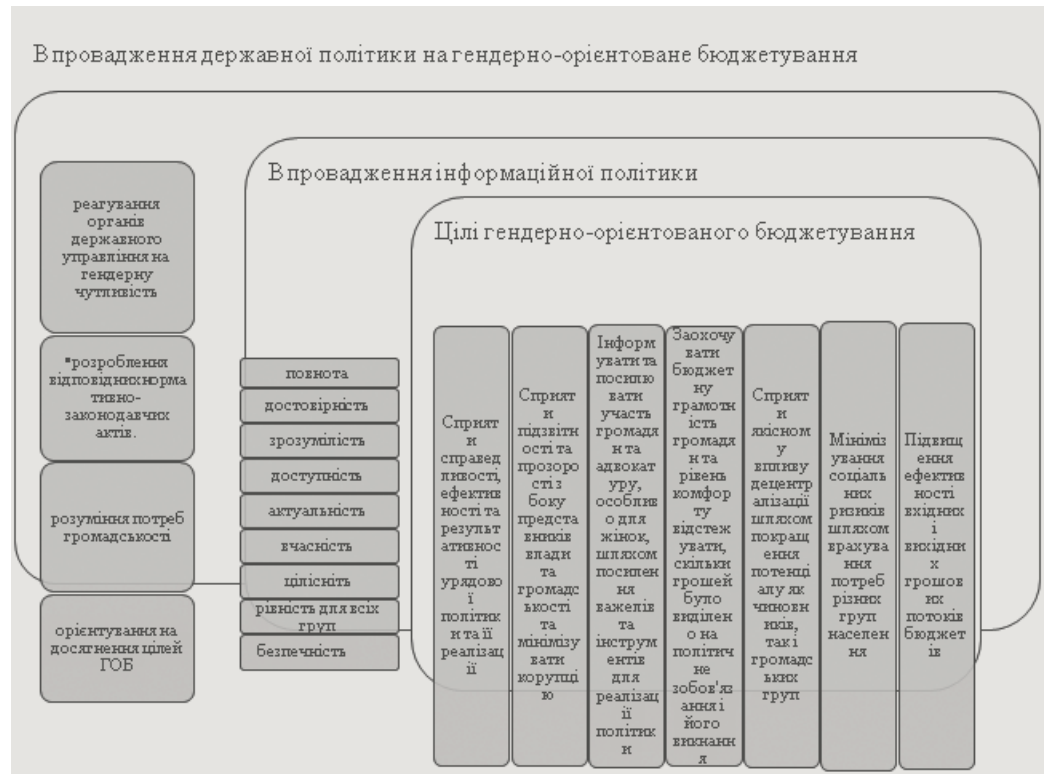

Puc.2. Державне управління у сфері гендерно-орієнтованого бюджетування (авторська розробка)

Таким чином, як видно при визначенні сценаріїв, можна визначити стратегії ГОБ до укрупнених цілей.

1. Стратегії підвищення рівня обізнаності та розуміння гендерних питань та наслідків.

Політика щодо бюджетів для чоловіків і жінок може зайняти кілька років для повноцінного розвитку. Через деякий час однак вони повинні враховувати звітність, бюджет та державне управління. Стратегії підвищення обізнаності охоплюють питання, пов〉язані 
3 даними, інструментами, як аналіз, прозорість інформації, підготовка та розбудова потенціалу. Ці стратегії необхідно залучити як урядом, так і громадянським суспільством та включити:

- розробку методів доступу, генерування та зберігання даних, розділених за статтю, використання їх у підготовці бюджету, плануванні та оцінці політики. Ці заходи складають найважливішу стратегію для всіх ГОБ, але вони здійснюються на різних рівнях країни залежно від наявності статистичних даних та ресурсів, розділених за статтю.

- розробка та застосування гендерно чутливих інструментів аналізу витрат та доходів до бюджетів та політики. Вони можуть варіюватися від відносно простої політики, орієнтованої на гендерну оцінку та опитування бенефіціарів на обсяг податків та виплат, що потребують ресурси для дослідження. Ця стратегія формується $і$ обмежується багатьма факторами, включаючи технічні навички залучених людей та наявність даних, розділених за статтю.

- створення та розповсюдження бюджетної та політичної інформації, щоб розширити розуміння переваг ГОБ та мотивувати до участі громадянське суспільство у прийнятті бюджетних рішень. Це означає, що прозорість є невід>ємним елементом мети підвищення обізнаності та розуміння гендеру стосовно бюджетів.

- спрямування уваги на гендерні проблеми та наслідки основних витрат та доходів, а не лише на конкретні цільові витрати на жінок та дівчат або стратегії доходу, які мають найбільш пряме значення для жінок чи чоловіків.

- систематичне вивчення та аналізування домашньої роботи i ïï впливу на бюджет та політику. Домашня робота, як неоплачена, так і оплачувана, характеризується сильним статевим розподілом праці.

- систематичне включення неформальної економіки в аналіз політики та бюджети. Важливість та гендерний характер неформальної економіки у багатьох країни також вимагають, щоб його аналіз був частиною ГОБ.

- визнаючи, що відповідна одиниця аналізу - людина чи домогосподарство - може бути різною за різних обставин. Крім 
того, якщо домогосподарство використовується як одиниця аналізу, тоді слід ретельно робити припущення щодо потужності та доступу до ресурсів. Доповідь Сьюзен Гіммельвейт у цьому томі надає приклади наслідків вибору одиниці аналізу для GRB.

- розробка аналізу значних перетинів статі 3 іншими категоріями аналізу, такими як соціально-економічний клас, раса, етнічна приналежність, місцевість, релігія та вік. Іноді відмінності між жінками або серед чоловіків можуть бути такими ж значущими для розуміння впливу на бюджет та політику, як і відмінності між жінками та чоловіками. Все більше свідчень про те, що нерівномірний вплив глобалізації - це зростаючі відмінності за класом, расою, місцевістю тощо. Жіночий бюджет Південної Африки приділяє особливу увагу перетину статі та раси. Бюджет місцевого самоврядування міста та округу Сан-Франциско у 1999 році прагнув розкрити ряд питань, що стосуються різних груп жінок та чоловіків.

- $\quad$ навчання та інші заходи з розбудови потенціалу з гендерного аналізу для бюрократії, парламентарів та громадянського суспільства.

- аналіз бюджету на різних рівнях: програмний сектор, міністерство / портфель, перехресний портфель, федеральний, штат, місцевий. Кожен з цих рівнів розкриває різні картини та розуміння гендерних питань.

2. Сприяти відповідальності уряду за зобов’язаннями щодо рівності статей.

Стратегії підзвітності прагнуть забезпечити відповідність між запланованими та фактичними показниками, а також контролювати зміни та прогрес стосовно економічної та соціальної рівності між чоловіками та жінками. Стратегії, що використовуються для росту підзвітності, включають:

- розробка категорій / рамок для звітування, які полегшують аудит та моніторинг у часі. Така стратегія варіюється від використання простих показників та цілей прогресу до гендерних показників до включення гендерних індикаторів і цільових показників у структуру бюджетування на основі ефективності, що визначає вхідні ресурси, оперативні ресурси та результати. 
- наповнення аналізу гендерниими наслідками при включення в бюджет та державної політики і повернення до процесів планування та оцінки політики уряду. Стратегія цього в деяких країнах полягала в тому, щоб вимагати оцінки впливу на гендерну роль в рамках процесу подання кабінету та нових схвалень витрат.

- ввітування про хід ГОБ міжнародним комітетам та конференціям та звітування за міжнародними документами та конвенціями, які уряди ратифікували.

- встановлення прихильності до бюджетів, що відповідають гендерним аспектам, на найвищих рівнях влади, 3 процесами, які мають чіткі лінії відповідальності за ключові бюджетні установи, такі як міністерство фінансів / казначейство та парламент. Внутрішні урядові ГОБ вимагають, щоб процеси та інститути підзвітності всередині влади були ефективними. Це, ймовірно, буде підтримуватися лише в тому випадку, якщо буде здійснюватися сильний тиск 3 боку громадянського суспільства.

- встановлення зв'язків між гендерними бюджетами та роботою загального аудиту уряду. Це може зробити свій внесок у моніторинг та прозорість, але його ще потрібно розробити.

- розробка стратегій громадянського суспільства, які потребують (юридично чи політично) відповіді уряду. Використовувані стратегії включають доступ до прав на інформацію щодо громадян (який застосовувався в Індії), внесення зобов'язань щодо гендерної рівності та їхніх бюджетних наслідків виборчим питанням, розміщення карток звітів (за допомогою засобів масової інформації та інших джерел) щодо прогресу уряду, розроблення альтернативного бюджету (наприклад, альтернативного федерального бюджету Канади), розробки списку пріоритетів бюджету людей (проект, що проводиться в Бангладеш) або безпосередньо участі у розробці проекту бюджету (місцева влада в Бразилія).

- регулярна звітність уряду перед громадськістю про вплив свого бюджету на чоловіків і жінок (наприклад, публікація заяви про жінок або бюджетного документу, як у випадку з австралійським федеральним та штатом урядів). 
- включення донорських цілей та мір успішності в процеси планування та оцінки.

- сприяння участі угруповань громадянського суспільства урядом у вправах ГОБ на базі громадянського суспільства.

Отже було продемонстровано, що існує декілька стратегій для підвищення гендерної обізнаності та розуміння і підзвітності у бюджетах та державній політиці. Стверджувалося також, що цим головним цілям ГОБ необхідно брати участь у більш широкому процесі досягнення змін до бюджетів та політики, які сприятимуть гендерній рівності. Хоча передбачається, що ці три основні цілі ГОБ не легко замінюються на цьому етапі дослідження, вибір шляхів їх досягнення порівняно багатий. Понад 40 країн, що експериментують 3 ГОБ, створюють все більшу кількість тематичних досліджень стратегій, які працюють, та стратегій, які є більш проблемними.

Очевидно, що для України слід врахувати запропоновані вище цілі і необхідно керуватися основними цілями. Тому в сучасних соціально-економічних умовах розвитку України слід розробити свої сценарії впровадження ГОБ.

Гендерне бюджетування - це процес висування гендерної перспективи на всіх етапах розробки політики. Виходячи з рекомендацій Статуту гендерного бюджету на 2007 рік, міністерство фінансів щорічно вживає коригуючих заходів для подолання гендерних розбіжностей у частині асигнувань на державні програми та схеми.

Як засвідчать наші дані, розрив у гендерній оплаті $є$ більшим для жінок кольорових, жінок на керівних посадах, жінок певних професій та галузей, а також у деяких штатах США. Пандемія СОVID (SARS) у 2020 року змусила значну частину населення працювати віддалено, із виходом за звичайні межі для деяких професій та галузей. Жінки мають більший ризик зазнати більших штрафних санкцій у заробітку. Жінки складають більший відсоток занять громадськими та соціальними послугами, освітою, бібліотеками та навчанням, службовою та адміністративною підтримкою та особистим доглядом та послугами, які, швидше за все, можуть бути припинені, звільнені або змушені працювати скороченим числом робочих годин. Жінки також мають більше шансів взяти відпочинкові 
роботи або навіть звільнитися з посади, щоб піклуватися про дітей, які вже не в школі, а також інших членів сім’і. Попередні дослідження PayScale також показали, що жінки часто зазнають штрафу за виплату після повернення на роботу після відсутності - в середньому на 7 відсотків менше за ту саму посаду. Слід встановити розрив у заробітній платі за гендерними категоріями працівників, які сильно впливають на коронавірус. Наприклад, вчителі початкових класів заробляють 0,92 долара за кожен долар, який складає чоловік. Стюардеси також складають 0,92 долара. Серед лікарів-медиків жінки сімейні лікарі (ОПЛ) заробляють 0,94 долара до долара, а медсестри - 0,98 долара. Це коли контролюються всі компенсуючі фактори. Жінки також складають 90 відсотків професії медичної сестри, яка загрожує значним ризикам для здоров'я, отримуючи менші виплати порівняно зі своїми колегами-чоловіками. У 2020 році у США стан гендерної різниці в оплаті праці становить 0,81 долара на один долар, зароблений чоловіками. Іншими словами, середня зарплата для чоловіків приблизно на 19 відсотків вища, ніж середня зарплата для жінок. Цей показник представляє 2-відсоткове покращення порівняно з 2019 роком та 7-відсоткове покращення порівняно 3 2015 роком, коли середня зарплата для чоловіків була приблизно на 26 відсотків вища, ніж середня зарплата для жінок.

Частина причини гендерної різниці в оплаті праці полягає в тому, що жінки частіше роблять перерву під час кар'єри (догляд за дітьми чи батьками), або шукати низькооплачувані посади, які пропонують більш гнучкий графік, щоб полегшити догляд за сім’єю. Деякі люди помилково припускають, що це «пояснює» гендерну різницю в заробітній платі та полегшує страх перед сексизмом. Однак це пояснення не повністю враховує розрив. Різниці в освіті, досвіді та професіях не відрізняються, як ми бачимо з контрольованої гендерної різниці в оплаті праці. Це також не заперечує сексизм на робочому місці.

Фактори, які можуть вплинути на розрив у гендерній оплаті, але їх важко виміряти, включають несвідоме упередження та дискримінацію жінок, включаючи припущення, що жінки залишатимуть робочу силу, щоб мати дітей, або що жінки з дітьми повинні заробляти 
менше, ніж чоловіки. В опитуванні 2017 року дослідницький центр Pew встановив: 42 відсотки жінок сказали, що зазнали гендерної дискримінації на роботі порівняно з 20 відсотками чоловіків, які сказали те саме. Однією з найпоширеніших форм дискримінації $є$ заробіток нерівності. Дійсно, 25 відсотків жінок сказали, що вони заробляють менше, ніж чоловік, який виконує ту саму роботу, тоді як лише 5 відсотків чоловіків сказали, що вони заробляють менше, ніж жінка, яка робить ту саму роботу. Жінки $з$ дітьми також менше працевлаштовані, ніж чоловіки з дітьми або жінки без дітей. Це часто називають покарання за материнство або покарання за народження дитини.

Дослідження також показує, що жінки займають більш низькооплачувані посади, ніж чоловіки. Хоча жінки сьогодні мають більшу представницькість на високооплачуваних робочих місцях, ніж тоді, коли було підписано Закон про рівну оплату понад 50 років але, жінки в цілому все ще недостатньо представлені у високооплачуваних робочих місцях та керівних ролях, особливо в C-Suite [12].

У світовій практиці також існують гендерні розриви. Дані Бюро статистики праці показують, що жінки складають більшу частину робочої сили у сферах підтримки, обслуговування та добробуту, таких як громадські та соціальні послуги, освіта, навчання та бібліотека, медичні працівники, охорона здоров'я, офісна та адміністративна підтримка, особиста гігієна та послуги.

В цьому випадку, різниця в заробітній платі за гендерним рівнем мала б бути меншою за професіями, де переважають жінки, проте дані не показали такої картини. Наприклад, жінки домінують у правовій галузі, а це 53 відсотки жінок та 47 відсотків чоловіків. Однак у законодавстві був найбільший розрив у заробітній платі за гендерними ознаками, що свідчить про те, що жінки та чоловіки статистично не мають однакових рівнів чи звань у юридичній професії.

Професії у сфері освіти, навчання та бібліотечній справі мають другий за величиною неконтрольований розрив у оплаті праці, незважаючи на те, що жінки складають переважну більшість у цих сферах. Жінки на цих роботах заробляють 0,72 долара за кожен долар, який заробляють чоловіки, хоча 74 відсотки цих працівни- 
ків - жінки. Жінки становлять більшу частину робочої сили цього сектора, багато хто працює в початковій освіті. Однак більшість чоловіків працюють в середній освіті, де основне навчання та адміністративні обов' язки є більш доступними, ніж у початкових школах. Такі лідерські можливості відкривають двері для наглядної та адміністративної ролі з більш високими зарплатами. Ці розбіжності посилюються, якщо сприймати шкідливі стереотипи про те, що у жінок низькі лідерські навички та навички у сфері управління фінансовими ресурсами.

Професії в галузі охорони здоров'я, ще одна галузь, де переважають жінки, мають найменший неконтрольований розрив у оплаті праці. Ці жінки заробляють 0,96 долара за кожен долар, який заробляють працівники служби охорони здоров'я. Жінки складають 87 відсотків працівників у цьому секторі, але все ще не отримують такого ж заробітку, як 13 відсотків колег-чоловіків. Жінки на робочих місцях у громадських та соціальних службах мають другий найменший розрив у гендерній оплаті - 0,96 дол.

Коли дані контролюються, різниця у заробітній платі за гендерну категорію до 2020 року зменшується для правничих професій та професій у сфері громадських та соціальних служб. Жінки в цих секторах заробляють $\$ 1,00$ за кожен долар, який заробляють чоловіки, контролюючи компенсуючі фактори. Контрольований розрив у оплаті праці працівників служби охорони здоров'я становить 0,98 дол. Тим часом професії з монтажу, обслуговування та ремонту продовжують мати найбільший контрольований гендерний розрив у 2020 році. Навіть після контролю за різними компенсаційними виплатами жінки в цих професіях заробляють лише 0,94 долара за кожен долар, який складає еквівалент чоловікові. Контрольована різниця в оплаті праці також значна для будівництва та видобутку $(0,96$ дол. США), освіти, навчання та бібліотечної справи, пов'язаних 3 приготуванням їжі та подачею їжі, управлінням, захисними послугами та продажами (0,97 дол. США) (табл.1). 
Таблиця 1

Гендерні розриви у заробітній платі чоловіків та жінок відповідно до сфер зайнятості у США у 2020 році*

\begin{tabular}{|c|c|c|c|}
\hline $\begin{array}{c}\text { Топ-20 робочих } \\
\text { місць із } \\
\text { різницею у } \\
\text { гендерній } \\
\text { різниці }\end{array}$ & $\begin{array}{l}\text { Контрольо- } \\
\text { вана } \\
\text { гендерна } \\
\text { різниця } \\
\text { в оплаті }\end{array}$ & $\begin{array}{c}\text { Середня } \\
\text { оплата - } \\
\text { чоловіки }\end{array}$ & $\begin{array}{l}\text { Контрольо- } \\
\text { вана } \\
\text { середня } \\
\text { оплата - } \\
\text { жінки }\end{array}$ \\
\hline 1. Анестезіологи & 0,83 дол & $\begin{array}{l}355000 \\
\text { доларів }\end{array}$ & $\begin{array}{l}296000 \\
\text { доларів }\end{array}$ \\
\hline $\begin{array}{l}\text { 2. Збирачі } \\
\text { електричного } \\
\text { та електронного } \\
\text { обладнання }\end{array}$ & 0,84 дол & $\begin{array}{l}34800 \\
\text { доларів }\end{array}$ & $\begin{array}{l}\text { 29,100 } \\
\text { доларів }\end{array}$ \\
\hline $\begin{array}{l}\text { 3. Сільськогоспо- } \\
\text { дарська галузь, } \\
\text { ранчо та інші } \\
\text { керівники сільського } \\
\text { господарства }\end{array}$ & 0,84 дол & $\begin{array}{c}46100 \\
\text { доларів }\end{array}$ & $\begin{array}{c}38800 \\
\text { доларів }\end{array}$ \\
\hline $\begin{array}{l}\text { 4. Оператори } \\
\text { упаковки та } \\
\text { наповнення машини }\end{array}$ & 0,85 дол & $\begin{array}{c}36400 \\
\text { доларів }\end{array}$ & $\begin{array}{c}30900 \\
\text { доларів }\end{array}$ \\
\hline 5. Модні дизайнери & 0,85 дол & $\begin{array}{l}58900 \\
\text { доларів }\end{array}$ & $\begin{array}{l}50000 \\
\text { доларів }\end{array}$ \\
\hline $\begin{array}{l}\text { 6. Комп’ютерні } \\
\text { оператори }\end{array}$ & 0,85 дол & $\begin{array}{l}45200 \\
\text { доларів }\end{array}$ & $\begin{array}{l}38600 \\
\text { доларів }\end{array}$ \\
\hline $\begin{array}{l}\text { 7. Офіціанти та } \\
\text { офіціантки }\end{array}$ & 0,86 дол & $\begin{array}{l}22800 \\
\text { доларів }\end{array}$ & $\begin{array}{r}19600 \\
\text { доларів }\end{array}$ \\
\hline 8. Водій & 0,86 дол & $\begin{array}{c}34300 \\
\text { доларів }\end{array}$ & $\begin{array}{l}29600 \\
\text { доларів }\end{array}$ \\
\hline $\begin{array}{l}\text { 9.Наглядові органи } \\
\text { за гральним } \\
\text { бізнесом }\end{array}$ & 0,88 дол & $\begin{array}{c}53800 \\
\text { доларів }\end{array}$ & $\begin{array}{c}47600 \\
\text { доларів }\end{array}$ \\
\hline
\end{tabular}


продовження таблиц̧і 1

\begin{tabular}{|c|c|c|c|}
\hline 10. Ювеліри & 0,89 дол & $\begin{array}{l}45000 \\
\text { доларів }\end{array}$ & 39800 доларів \\
\hline $\begin{array}{l}\text { 11. Працівники } \\
\text { хімічної галузі }\end{array}$ & 0,89 дол & $\begin{array}{l}46200 \\
\text { доларів }\end{array}$ & 40900 доларів \\
\hline $\begin{array}{l}\text { 12. Оператори } \\
\text { хімічного } \\
\text { обладнання та } \\
\text { тендери }\end{array}$ & 0,89 дол & $\begin{array}{c}40800 \\
\text { доларів }\end{array}$ & $\begin{array}{c}36100 \\
\text { доларів }\end{array}$ \\
\hline $\begin{array}{l}\text { 13. Патрульні } \\
\text { поліцейські та } \\
\text { шерифи }\end{array}$ & 0,89 дол & $\begin{array}{c}50600 \\
\text { доларів }\end{array}$ & 45000 доларів \\
\hline $\begin{array}{l}\text { 14. Музичні } \\
\text { керівники та } \\
\text { композитори }\end{array}$ & 0,89 дол & $\begin{array}{c}46100 \\
\text { доларів }\end{array}$ & 41000 доларів \\
\hline $\begin{array}{l}\text { 15. Диспетчери, крім } \\
\text { поліції, пожежних та } \\
\text { швидкої допомоги }\end{array}$ & 0,89 дол & $\begin{array}{c}41900 \\
\text { доларів }\end{array}$ & 37300 доларів \\
\hline $\begin{array}{l}\text { 16. Художники, } \\
\text { включаючи } \\
\text { живописців, } \\
\text { скульпторів та } \\
\text { ілюстраторів } \\
\end{array}$ & 0,89 дол & $\begin{array}{c}47200 \\
\text { доларів }\end{array}$ & $\begin{array}{r}42000 \\
\text { доларів }\end{array}$ \\
\hline $\begin{array}{l}\text { 17. Техніки } 3 \\
\text { електротехніки та } \\
\text { електроніки }\end{array}$ & 0,89 дол & $\begin{array}{c}49300 \\
\text { доларів }\end{array}$ & 43900 доларів \\
\hline $\begin{array}{l}18 . \text { Фахівці з } \\
\text { надзвичайних } \\
\text { ситуацій }\end{array}$ & 0,89 дол & $\begin{array}{c}61800 \\
\text { доларів }\end{array}$ & 55200 доларів \\
\hline $\begin{array}{l}\text { 19. Супервізори } \\
\text { першого ряду }\end{array}$ & 0,90 дол & $\begin{array}{r}44600 \\
\text { доларів } \\
\end{array}$ & 39900 доларів \\
\hline $\begin{array}{l}\text { 20. Торгові } \\
\text { представники, } \\
\text { послуги, все інше }\end{array}$ & 0,90 дол & $\begin{array}{c}54800 \\
\text { доларів }\end{array}$ & 49100 доларів \\
\hline
\end{tabular}

*складено авторкою на основі [11-13] 
Сучасне розуміння гендерних відмінностей у поведінці та того, як державна політика по-різному впливає на чоловіків та жінок, покращилось за останні роки і впливає на макроекономічну політику, особливо на фіскальну політику.

Сучасне розуміння гендерних відмінностей у поведінці та того, як державна політика по-різному впливає на чоловіків та жінок, покращилось за останні роки і впливає на макроекономічну політику, особливо на фіскальну політику. Основним завданням у сфері публічного управління 3 приводу гендерно-орієнтованого бюджетування $\epsilon$ інформування всіх груп стейкхолдерів та роз'яснення методики гендерно-орієнтованого бюджетування. 3 цією метою в Україні вже було здійснено роботу шляхом проведення ряду тренінгів в рамках фінансування Фондом ім. Фрідріка Еберта. Проте, врахувавши досвід іноземних держав, а також в умовах аналізування наукових досліджень у цій сфері, слід удосконалити роз'яснення методики гендерно-орієнтованого бюджетування. В рамках наукового пошуку інноваційних механізмів управління соціальними ризиками, відзначимо, що гендерна відмінність це відмінність не лише за статтю, а й за конкретними потребами в силу ментальних, соціальних, етнічних, расових, релігійних відмінностей. Проте, слід врахувати той факт, що на сьогодні в Україні застосування гендерно-орієнтованого бюджетування не може охопити весь бюджетний процес в силу фінансового обмеження. Так, у 2020 році гендерно-чутливих паспортів є 930 у порівнянні з 2019 - 325 [12].

Важливим $\epsilon$ i те, що існуючі обмеження у фінансуванні програм вимагають розроблення методики Враховуючи зазначене, удосконалено етапи гендерно-орієнтованого бюджетування (табл. 2).

Таблиця 2 
Процес удосконалення етапів впровадження ГОБ*

\begin{tabular}{|c|c|c|}
\hline Етапи & $\begin{array}{c}\text { Наявні в } \\
\text { методиці під } \\
\text { етапи }\end{array}$ & Пропоновані підетапи \\
\hline \multirow{3}{*}{$\begin{array}{l}\text { 1. Етап. } \\
\text { Оцінка } \\
\text { вихідної } \\
\text { ситуації і } \\
\text { можлив } \\
\text { остей для } \\
\text { роботи в } \\
\text { конкретній } \\
\text { сфері }\end{array}$} & $\begin{array}{l}1.1 \text { Аналіз } \\
\text { зацікавлених } \\
\text { сторін. } \\
\text { Визначення } \\
\text { цільових груп і } \\
\text { бенефеціарів }\end{array}$ & $\begin{array}{l}\text { Необхідно застосувати СВОТ- } \\
\text { аналіз, який враховуватиме } \\
\text { слабкі і сильні сторони } \\
\text { можливості та загрози в межах } \\
\text { конкретної територіальної } \\
\text { громади чи в межах окремої } \\
\text { програми. }\end{array}$ \\
\hline & $\begin{array}{l}1.2 \text { Оцінка } \\
\text { організацій- } \\
\text { них і кадрових } \\
\text { передумов } \\
\text { реалізації }\end{array}$ & $\begin{array}{l}\text { До під етапів необхідно додати } \\
\text { аналіз інформаційної політики } \\
\text { у сфері побудови гендерно- } \\
\text { орієнтованого бюджетування } \\
\text { (шляхом опитування населення, } \\
\text { аналізування інформації у } \\
\text { засобах масової інформації тощо) } \\
\end{array}$ \\
\hline & $\begin{array}{l}1.3 \text { Складання } \\
\text { «гендерного } \\
\text { профілю» }\end{array}$ & $\begin{array}{l}\text { Необхідно додати } \\
\text { ретроспективний аналіз якісних } \\
\text { даних на конкретній території (в } \\
\text { ході децентралізації необхідно } \\
\text { структурувати ментальні, } \\
\text { географічні, релігійні, етнічні } \\
\text { особливості) }\end{array}$ \\
\hline
\end{tabular}


продовження таблиці 2

\begin{tabular}{|c|c|c|}
\hline \multirow{4}{*}{$\begin{array}{l}\text { 2. Етап. } \\
\text { Проведення } \\
\text { гендерного } \\
\text { аналізу } \\
\text { бюджету } \\
\text { (галузі/ } \\
\text { програми, } \\
\text { заходів) }\end{array}$} & $\begin{array}{l}2.1 \text { Оцінювання } \\
\text { вартості послуг }\end{array}$ & $\begin{array}{l}\text { Необхідне структурування також } \\
\text { за віком осіб. }\end{array}$ \\
\hline & $\begin{array}{l}2.2 \text { Оцінювання } \\
\text { витрат на } \\
\text { персонал }\end{array}$ & $\begin{array}{l}\text { Аналогічно необхідно здійснити } \\
\text { аналізування щодо вікової } \\
\text { структури персоналу }\end{array}$ \\
\hline & $\begin{array}{l}2.3 \\
\text { Порівняльний } \\
\text { аналіз } \\
\text { фінансування } \\
\text { галузі/програми } \\
\text { за роками }\end{array}$ & $\begin{array}{l}\text { Застосування порівняльного } \\
\text { аналізу з іншими регіонами, } \\
\text { програмами, країнами та } \\
\text { побудова трендів }\end{array}$ \\
\hline & $\begin{array}{l}2.4 \text { Оцінювання } \\
\text { ефективності } \\
\text { послуг }\end{array}$ & $\begin{array}{l}\text { Застосування якісного } \\
\text { оцінювання ефективності } \\
\text { послуг (шляхом опитування, } \\
\text { анкетування) }\end{array}$ \\
\hline \multirow{2}{*}{$\begin{array}{l}\text { 3. Ідентифі- } \\
\text { кація } \\
\text { гендерно- } \\
\text { специфіч- } \\
\text { них } \\
\text { проблем, } \\
\text { мети та } \\
\text { завдань ГБ }\end{array}$} & $\begin{array}{l}3.1 \text { Аналіз } \\
\text { наявних фактів } \\
\text { гендерної } \\
\text { нерівності, } \\
\text { а також } \\
\text { політичних } \\
\text { рішень і заходів, } \\
\text { що посилюють } \\
\text { таку нерівність } \\
\end{array}$ & $\begin{array}{l}\text { Доцільно провести аналіз } \\
\text { інформаційної політики відносно } \\
\text { конкретної програми чи } \\
\text { територіальної одиниці }\end{array}$ \\
\hline & $\begin{array}{l}3.2 \text { Формування } \\
\text { гендерно- } \\
\text { специфічної } \\
\text { мети та завдань } \\
\text { бюджетної } \\
\text { політики, } \\
\text { спрямованих } \\
\text { на розв’язання } \\
\text { гендерно- } \\
\text { специфічних } \\
\text { проблем }\end{array}$ & $\begin{array}{l}\text { Перед цим підетапом необхідно } \\
\text { ідентифікувати передумови } \\
\text { виникнення гендерної нерівності }\end{array}$ \\
\hline
\end{tabular}


продовження таблищі 2

\begin{tabular}{|c|c|c|}
\hline \multirow{3}{*}{$\begin{array}{l}\text { 4. Формува- } \\
\text { ння } \\
\text { гендерно- } \\
\text { чутливих } \\
\text { бюджетних } \\
\text { пропозицій }\end{array}$} & $\begin{array}{l}4.1 \text { Визначення } \\
\text { заходів у } \\
\text { рамках бюджету } \\
\text { сектора/ } \\
\text { програми, які } \\
\text { сприятимуть } \\
\text { досягненню } \\
\text { гендерної } \\
\text { ріавності }\end{array}$ & $\begin{array}{l}\text { В межах планування декількох } \\
\text { заходів в умовах обмеженості } \\
\text { фінансових ресурсів необхідно } \\
\text { застосувати А/В - тестування, } \\
\text { що значною мірою спростить } \\
\text { впровадження всіх попередніх } \\
\text { етапів }\end{array}$ \\
\hline & $\begin{array}{l}4.2 \text { Розрахунок } \\
\text { витрат на } \\
\text { досягнення } \\
\text { цілей гендерної } \\
\text { рівності }\end{array}$ & $\begin{array}{l}\text { Обгрунтування цих витрат, } \\
\text { як подальше скорочення } \\
\text { фінансового напруження на } \\
\text { бюджет та як один з інструментів } \\
\text { мінімізації соціальних ризиків } \\
\text { та підняття ефективності } \\
\text { соціальних послуг }\end{array}$ \\
\hline & $\begin{array}{l}4.3 \text { Визначення } \\
\text { структури } \\
\text { відповідаль- } \\
\text { ності та } \\
\text { фінансування } \\
\end{array}$ & $\begin{array}{l}\text { Необхідно додати застосування } \\
\text { методів HR- менеджменту в } \\
\text { системі управління персоналом } \\
\text { на досягнення поставлених цілей } \\
\text { гендерної рівності }\end{array}$ \\
\hline \multirow{3}{*}{$\begin{array}{l}\text { 5. Оцінка } \\
\text { гендерного } \\
\text { впливу } \\
\text { планованих } \\
\text { бюджетних } \\
\text { заходів }\end{array}$} & $\begin{array}{l}\text { 5.1 Аналіз } \\
\text { соціально- } \\
\text { економічного } \\
\text { впливу на окремі } \\
\text { гендерні групи } \\
\end{array}$ & $\begin{array}{l}\text { Слід додати не лише окремі } \\
\text { гендерні групи, але й на } \\
\text { загально-державному чи } \\
\text { територіальному рівні }\end{array}$ \\
\hline & $\begin{array}{l}\text { 5.2 Аналіз } \\
\text { можливих } \\
\text { втрат у разі не } \\
\text { впровадження } \\
\text { пропонованих } \\
\text { втручань } \\
\end{array}$ & \\
\hline & $\begin{array}{l}5.3 \text { Аналіз } \\
\text { ризиків під час } \\
\text { впровадження } \\
\text { планового } \\
\text { втручання } \\
\end{array}$ & $\begin{array}{l}\text { Виокремлення та аналіз наслідків } \\
\text { в розрізі розгляду саме цих } \\
\text { соціальних ризиків. Побудова } \\
\text { системи управління цими } \\
\text { соціальними ризиками }\end{array}$ \\
\hline
\end{tabular}

*Удосконалено автором на основі $[11,13,14]$ 
Ці етапи є необхідними на початковому впровадженні ГОБ. Але в подальшому пропонується застосування A/B- тестування. Також саме застосування цього методу є визначальним в умовах карантину, адже бажується на використанні цифрових технологій. Слід врахувати, що А/В -тестування дозволить оптимізувати бюджети.

Історично бюджети складання бюджетів носив суто технічний характер: збалансування доходів і витрат в рамках обмежених ресурсів. Як такі, вони вважалися «гендерно нейтральними». Використання підходу до гендерного аналізу для отримання доходів та розподілу ресурсів допомагає поліпшити розуміння того, як рішення по-різному впливають на жінок та чоловіків через їхній досвід у структурах сім’ї та домогосподарств, працевлаштування, догляду та забезпечення інших. Те, як ресурси розподіляються на послуги, на соціальне страхування або як підвищуються податки, по-різному впливає на жінок та чоловіків. Отже, управлінці 3 державних фінансів вимагають усвідомлення різноманітних реалій життя людей та характеристик, що структурують досвід людей щодо державних служб, включаючи простори та установи, якими вони прагнуть користуватися.

Гендерний аналіз впливу на жінок та чоловіків пропонує підхід до формування політики та управління державними фінансами, що покращує формування політики та бюджетування на основі результатів у державному управлінні. Спочатку гендерне бюджетування може здатися зіткненням двох різних світів - державних фінансів та соціальної справедливості. Це розуміння стверджує, що гендерне бюджетування - це підхід до управління державними фінансами, який прагне виявити стійкі нерівності, щоб державні ресурси могли бути спрямовані на найкращий ефект для їх вирішення.

Тестування А / В пропонує дуже систематичний спосіб 3'ясувати, ефективність будь- якого процесу. Цей тест побудований на основі застосування маркетингових технологій у сфері цифрової економіки. Більшість маркетингових зусиль спрямовані на збільшення трафіку. Зокрема і у випадку розширення застосування гендерного підходу можна розглядати зусилля його прихильників через призму маркетингу i позиціонувати його як ефективний 
спосіб мінімізації соціального ризику та покращення соціальноекономічного стану в країні. Зокрема орієнтація на цифровий простір вимагає гнучкості у ГОБ і розширення трафіку. Але, оскільки придбання трафіку є складним та вартісним, то стає першорядним пропонувати найкращий досвід стейкхолдерам, які заходять веб-сайти 3 питань ГОБ. Це допоможе їм досягти поставлених цілей і дозволить здійснити конвертацію у найшвидший та найефективніший спосіб. Тестування А / В в маркетингу дозволяє максимально використати наявний трафік. Структурована програма тестування A/B може зробити маркетингові зусилля більш вигідними, визначивши найважливіші проблемні області, які потребують оптимізації і застосування гендерного бюджетування. В практиці комерційних підприємств застосування тестування А / В відходить від самостійної діяльності, яка обмежувалася періодичністю 1 раз на місяць до більш структурованої та безперервної i, яку завжди слід проводити за допомогою чітко визначеного процесу. Звичайно, що при застосуванні A/B - тестуванні застосовується лише два можливих варіанти, тобто дві можливих програми або напрямки, проте слід врахувати і багатоваріатність можливих програм. Але для визначення та оптимізації процесів та в умовах карантинних обмежень $є$ необхідним використання цифрових технологій. Google Analytics i Google Optimize пропонують одне з найкращих рішень для збору даних та тестування А / B, i дають можливість отримати майже все необхідне безкоштовно. Набір Google Analytics 360 включає в себе оптимізацію 360 і надає великий спектр інструментів у безкоштовній версії. Проте важливим $є$ наявність фахівця, який знає, як налаштувати розширене стеження. Це головний недолік варіанту Google: потрібно знати платформу та як отримати найкраще 3 неї, і це вимагатиме відповідної технічної підготовки фахівця. Застосування цього виду тестування значно спростить роботу над виявленням гендерно-чутливих бюджетів чи тих сфер, які потребують найбільшого втручання, або які є найменш гендерно чутливими [15].

Спроектуємо етапи впровадження А / В - тестування для гендерного бюджетування (табл.3). 
Таблиця 3

\section{Пропоновані етапи впровадження А / B - тестування для гендерного бюджетування}

\begin{tabular}{|c|c|}
\hline Етапи & Опис \\
\hline Цілі тестування & $\begin{array}{l}\text { Збільшення читацької аудиторії та аудиторії, } \\
\text { збільшенні підписок, збільшенні часу, } \\
\text { проведеного відвідувачами на їхньому веб- } \\
\text { сайті, або прискоренні перегляду відео } \\
\text { та інших матеріалів із використанням } \\
\text { соціального обміну }\end{array}$ \\
\hline Вимір & Планування програми тестування \\
\hline $\begin{array}{l}\text { Встановле- } \\
\text { ння } \\
\text { пріоритетів }\end{array}$ & $\begin{array}{l}\text { Визначення пріоритетів допомагає науково } \\
\text { сортувати декілька гіпотез. На даний } \\
\text { момент слід отримати данні веб-сайту, дані } \\
\text { про відвідувачів і чітко визначити цілі. } \\
3 \text { відставанням, який було підготовлено } \\
\text { на першому етапі разом } 3 \text { гіпотезою, та } \\
\text { визначення пріоритетності. }\end{array}$ \\
\hline Умови & $\begin{array}{l}\text { Чіткі часові виміри тестування, яких необхідно } \\
\text { дотримуватися, випадковість дослідження } \\
\text { (рендомний підхід), безперервність проведення } \\
\text { тестів (тобто вибірка має бути постійно), } \\
\text { Не нехтувати тими варіантами, які не принесли } \\
\text { результати. } \\
\begin{array}{l}\text { Вибірка (гіпотези) має мати причинно- } \\
\text { наслідковий зв’язок. }\end{array}\end{array}$ \\
\hline $\begin{array}{l}\text { Конкретизація } \\
\text { вимірів } \\
\text { тестування }\end{array}$ & $\begin{array}{l}\text { Конкретна соціальна кнопка, яка доступна у } \\
\text { публічних закладах (н.п. ЦНАП) } \\
\text { Тестування варіантів режимів реєстрації } \\
\text { електронною поштою }\end{array}$ \\
\hline $\begin{array}{c}\text { Складання } \\
\text { календаря } \\
\text { тестування }\end{array}$ & $\begin{array}{l}\text { Ефективна програма оптимізації завжди } \\
\text { матиме дві частини, а саме планувати та } \\
\text { визначати пріоритети }\end{array}$ \\
\hline
\end{tabular}


продовження табличі 3

\begin{tabular}{|c|l|}
\hline Внесення змін & $\begin{array}{l}\text { Необхідно аналізувати всі отримані } \\
\text { результати здійснити, внести зміни. }\end{array}$ \\
\hline \multirow{2}{*}{ Ефективність } & $\begin{array}{l}\text { Вибір оптимального варіанту гендерна } \\
\text { чутливої соціальної програми. } \\
\text { Більш ефективний процес аналізування } \\
\text { гендерних даних. } \\
\text { Підвищення поінформованості населення. }\end{array}$ \\
\hline
\end{tabular}

Саме застосування такого методу тестування до вирішення тих чи інших питань впровадження гендерного бюджетування дозволить вирішити проблеми обрання найбільш ефективні варіанти. Адже гендерне бюджетування виходить 3 того, що спосіб залучення або розподілу ресурсів має наслідки, оскільки політика чи програми, що фінансуються, порізному впливають на жінок та чоловіків. Однак гендерна нерівність вплетена в інституційні практики, включаючи бюджетні процеси, і є однією з основних причин необхідності державного управління.

Зменшення гендерної нерівності може призвести до покращення макроекономічних показників. Визнання того, що гендерні розбіжності є шкідливими та що державні бюджети не $є$ гендерно нейтральними, означає необхідність включення гендерних міркувань у процес складання бюджету. Хоча ініціативи гендерного бюджетування можуть приймати різні форми, їх найважливіше призначення - впливати на процес бюджетування та допомагати розробникам політики зосереджуватися на шляхах, завдяки яким державна політика може допомогти зменшити гендерні нерівності та покращити економічні результати.

Висновки. У цій статті розглядалось, як ефективно забезпечити процес впровадження гендерних перспектив у бюджетний процес шляхом впровадження нових напрямків державного управління. В процесі дослідження було описано 
різні підходи до побудови стратегій державного управління у сфері гендерно-орієнтованого бюджетування, виділивши цілі і напрямки їх дослідження, яке було виявлено на основі детального огляду структури поточної системи гендерного бюджетування. В дослідженні виділено та обгрунтовано необхідність поширення гендерно-орієнтованого бюджетування на всіх рівня. Для цього було встановлено, що спільно з кількісними підходами аналізування гендерних ініціатив, слід застосувати і якісні, виконання яких дозволить здійснити впровадження А/B - тестування. Таке тестування може бути одним 3 напрямків державного управління у сфері гендерно-орієнтованому. Враховуючи сучасні умови соціальної кризи, зумовленої пандемією, подальшими напрямками дослідження є розкриття особливостей в цих умовах гендерно-орієнтованого бюджетування.

\section{Стаття надійшла до редакції: 18.09.20}

\section{JUSTIFICATION OF THE DIRECTIONS OF PUBLIC ADMINISTRATION IN THE FIELD OF GENDER-ORIENTED BUDGETING}

Olena Bilyk, PhD, associate professor, associate professor of the department of administrative and financial management, Lviv Polytechnic National University, Lviv, Ukraine.

The article highlights the features of gender budgeting and the need for its application in public administration. The presented theses on gender-oriented budgeting (GOB) in public administration are based on the experience of developed countries, taking into account the problems associated with gender budgeting, in order to study and justify the 
actions direction at the beginning of the integration of gender public administration. For the past 25 years, the international community has recognized the importance of gender equality for sustainable economic growth and full social development, and has called on countries to use their budgets to promote the allocation of resources and income on a gender basis. More than 60 countries have responded to this call by implementing gender-sensitive budgets at the national and subnational levels. The GOB goals can be seen as hierarchical to some extent at the initial stage of implementation in many countries, GOB typically focuses on strategies aimed at raising awareness of gender policy and budgets (e.g., collecting data divided by gender, training civil servants, developing gender-sensitive analysis). However, good information and analysis of gender issues and the implications of policy and budget are not in themselves sufficient to change budgets if public officials cannot be called upon to carry out their actions in the field of gender equality. The study described different approaches to building public administration strategies in the field of gender-based budgeting, highlighting the goals and directions of their study, which was found on the basis of a detailed review of the structure of the current gender budgeting system. It is proved that the application of gender-sensitive budgeting in the public administration system will minimize social risks that can have a destructive effect on public finances. The article reveals possible strategies of gender-oriented budgeting, and also offers a qualitative method for determining the priority of the implementation of certain gender programs, based on A/B-testing.

Key words: gender-oriented budgeting, public administration, gender-oriented budgeting strategies, a / c-testing, social risks, gendersensitive areas.

\section{Received: 18.09 .20}

\section{References}

1. Maihofer, A. (2006). Von der Frauen- zur Geschlechterforschung. Ein bedeutsamer Perspektivenwechsel nebst aktuellen Herausforderungen an die 
Geschlechterforschung. In: Brigitte Aulenbacher (Hg.): FrauenMännerGeschl echterforschung. State of the art. 1. Aufl. Münster: Westfälisches Dampfboot. Forum Frauen- und Geschlechterforschung, 19, 64-77 [in German].

2. Heister, M. (2007). Gefühlte Gleichstellung. Zur Kritik des Gender Mainstreaming. Königstein/Taunus: Helmer. Konzepte, Materialien, 5 [in German].

3. Hensel, J. (2020). Gleichberechtigung. Die Krise der Männer. Retrieved from www.zeit.de/gesellschaft/zeitgeschehen/2020-04/gleichberechtigungcoronavirus-maenner-frauenwissenschaftler-politiker-systemrelevante-berufe [in German].

4. Sen, A. (1995). Inequality Reexamined. New York: Oxford University Press [in English].

5. Hageman, S. (2012). Negotiations of the European Union Budget: How Decision Processes Constrain Policy Ambitions, in Benedetto, Giacomo (ed.), European Union Budget Reform. London: Palgrave, 23-39 [in English].

6. Ogorodova, T. (2019). Henderne biudzhetuvannia spryiaie pidvyshchenniu efektyvnosti derzhavnykh vytrat ta derzhavnoi polityky [Gender budgeting helps to increase the efficiency of public spending and public policy]. Retrieved from http: http://pleddg.org.ua/en/2019/genderno-oriientovanebyudzhetuvannya-s/ [in Ukrainian].

7. Hrytsai I.O. (2018). Pryntsyp hendernoi rivnosti ta mekhanizm yoho zabezpechennia: teoretyko-pravovyi aspect [The principle of gender equality and the mechanism of its provision: theoretical and legal aspect] [in Ukrainian].

8. Nalyvaiko, L. \& Fomina, D. (2019). Application of gender-based budgeting in ukraine: problems of theory and practice. Retrieved from http:// www.jurnaluljuridic.in.ua/archive/2019/2/part_2/6.pdf [in English].

9. Fesenko, T.H. (2017). Kontent-analiz upravlinnia proektamy hendernoho biudzhetuvannia [Content analysis of gender budgeting project management]. Upravlinnia rozrobkoiu skladnykh system - Management of complex systems developmen, 30, 84-91 [in Ukrainian].

10. Country Specific Information. European institute for gender equality. eige.europa.eu. Retrieved from http: http://eige.europa.eu/gendermainstreaming/ countries [in English].

11. Henderno-oriientovane biudzhetuvannia na mistsevomu rivni: vid intehratsii pryntsypu hendernoi rivnosti do biudzhetnoho protsesu do henderno 
chutlyvykh predstavnykiv [Gender-oriented budgeting at the local level: from integration of the principle of gender equality into the budget process to gendersensitive representatives]. decentralization.gov.ua. Retrieved from https:// decentralization.gov.ua/uploads/library/file/599/gender-responsive_budgeting _ on_a_local_level_ukraine.pdf [in Ukrainian].

12. The state of the gender pay gap. Retrieved from https://www.payscale. com/data/gender-pay-gap [in English].

13. Henderno-oriientovane biuzhetuvannia [Gender-oriented budgeting]. www.facebook.com. Retrieved from https://www.facebook.com/search/top/?q= $\% \mathrm{D} 2 \% 91 \% \mathrm{D} 0 \% \mathrm{~B} 5 \% \mathrm{D} 0 \% \mathrm{BD} \% \mathrm{D} 0 \% \mathrm{~B} 4 \% \mathrm{D} 0 \% \mathrm{~B} 5 \% \mathrm{D} 1 \mathrm{D} 0 \% \mathrm{BA} \% \mathrm{D} 1 \% 80 \% \mathrm{D}$ $0 \% \mathrm{~B} 0 \% \mathrm{D} 1 \% 97 \% \mathrm{D} 0 \% \mathrm{BD} \% \mathrm{D} 1 \% 96 \&$ epa $=\mathrm{SEARCH} B \mathrm{BOX}$ [in Ukrainian].

14. Gender-oriented budgeting in Ukraine: theory and practice (2016), 6376 [in English].

15. A/B Testing Guide. vwo.com. Retrieved from https://vwo.com/abtesting/?utm_campaign=tof_ugc [in English].

\section{Відомості про авторів / Information about the Authors}

Білик Олена Іванівна: Національний університет «Львівська політехніка», м. Львів, 79000, Україна, вул. м. Львів, Україна.

Olena Bilyk: Lviv Polytechnic National University, 12 Stepan Bandera Str., Lviv, 79000, Ukraine.

\section{ORCID.ORG/ 0000-0002-7110-7257}

E-mail: Olena.i.bilyk@lpnu.ua 